\title{
IMPLEMENTATION OF THE GPS-TRACKING SYSTEM IN BULGARIAN MILITARY ORIENTEERING CHAMPIONSHIPS
}

\author{
Silvia Shandurkova \\ National Sports Academy "Vassil Levski" (Bulgaria)
}

\begin{abstract}
This paper discusses the characteristics and implementation of the GPS navigation system Tracksport in the Bulgarian military orienteering championships. The real-time tracking was used to analyze the parameters of the races, the speed and the optimal route choices in the discussed orienteering military events. The research methods were observation and visualization of the data received from portable GPStransmitters which used the available GSM-networks and their software processing for displaying real-time GPS tracking during the competitions. The contingent of the study were 41 women and 64 man who participated in the championships. The analysis reveals the necessity for GPS-tracking of such competitions and that it is an important precondition for improving their quality and understanding.
\end{abstract}

Keywords: military orienteering championships; GPS-tracking; tracksport system

\section{Introduction}

Orienteering was pioneered in Scandinavia as a military-applied sport. Major Ernst Kilander organized in Sweden one of the first official events in 1918. It was a result of his concern for a falling interest in athletics and a lack of use of the forest environment (McNeill 2010,8). The sport spread to the neighbor countries and then to Europe, gradually gaining more and more popularity.

The International orienteering Federation (IOF) was founded in 1961 and aims to promote the development of orienteering in its member countries.

According to IOF, orienteering is a sport in which the competitors navigate independently through the terrain. Competitors must visit a number of control points marked on the ground in the shortest possible time aided only by a map and a compass. The course, defined by the location of the controls, is not revealed to competitors until they start ${ }^{1}$.

The Global Positioning System (GPS) consists of 24 satellites operating in a single network, moving in 6 orbits at $17,000 \mathrm{~km}$ altitude. The satellites move continuously at an approximate speed of $3 \mathrm{~km} / \mathrm{s}$, making two complete circles around the Earth in 
less than 24 hours, transmitting coded signals that are received by small devices on Earth. GPS reads the signal sent by at least four satellites simultaneously and solves with extreme accuracy several complex equations to determines the location of the device in three-dimensional space (latitude, longitude and altitude) (Shopov 2019). Constantly recording the location for some time (tracking), the receiver determines the speed and the direction of the movement. With this system, it is possible to determine the exact location of each subject on the earth's surface (Shandurkova 2019).

During the last decades the technologies that offer tracking the location of moving objects developed rapidly. Live GPS tracking in orienteering has been conducted for first time during the World Orienteering Championships in Finland, 2001.However, at this stage the technology was quite expensive, which limited the possibilities for its use and analysis. (Kocbach 2011)

After 2004, the need for attractive presentation and systematic analysis of a group of competitors led to developing the analysis software and the number of special providers for live tracking has been increased. More and more tracked events were recorded. (Shandurkova 2019).

One of the Bulgarian GPS tracking systems introduced in orienteering is Tracksport system, created in 2014 from the engineer Victor Tzenkov. The name of the system is derived from the purpose of its usage - tracking moving objects in sports events ${ }^{2}$. (Tzenkov 2014)

The feedback from the Tracksport system visualizes the key moments in the race and allows the coach to analyze and make a more in-depth analysis of the competitors' performance. The coach has then the opportunity to monitor the parameters of the race. The tracking system can automatically generate a list of final results, which facilitates organizers in data processing. At the same time, the GPS signal makes it possible to track all participants at any time during the training or competition, which significantly increases the safety of participants. GPS signal tracking can also be used to support certain jury decisions. (Sirakov \& Dimitrova 2019)

A significant problem in analyzing orienteering races is that the achievements are very difficult to measure. In athletics when the training process is going well, the time and achievements improve, but in orienteering it is it is not so clear. If a quality GPS analysis of orienteering trainings and competitions is available, it is possible to assess certain indicators and analyze the route choices, the speed, the elevation, some specific parameters like entering and leaving the control point and deviation from the desired direction. (Sirakov, Dimitrova 2016)

The specificities of orienteering perfectly combine with the military activities. The Bulgarian military championships contains two disciplines: one-stage competition and a mixed relay formed by four competitors with at least one woman. The distance varies from two to six kilometers. The team results are formed by the sum of the best two times of each team in the one-stage competition, to which the times of the three men in the relay are added. The complex team ranking for women is formed by the 
best time of the one-stage competition for women, and the time of the woman from the relay. If a team's relay does not complete the relay, then the team only qualifies with the times of the one-stage competition. The technical part of the course is in accordance with the regulations of the Bulgarian Orienteering Federation.

The aim of this study was to analyze the application of the Tracksport GPS system in the Bulgarian military orienteering competition. The tasks of the research were:

1. To characterize the parameters of the Bulgarian military orienteering competition.

2. To characterize of the Tracksport system for orienteering analysis during the Bulgarian military orienteering competition.

3. To identify the specific analysis options arising from the GPS tracking.

\section{Methods}

The research methods were the visualization of the data received from portable GPS-transmitters, transmitted through the GSM-network and their software processing for real-time GPS tracking. The contingent of the study were 105 competitors - 41 women and 64 men started in the championships.

\section{Results}

The tracking of the military orienteering events began in 2016. Twelve events were created in the Tracksport system for five years - three women races, three men races and six relays. Simultaneous tracking provides quick visual information about the movement of the group. But additionally, it is possible to present a graphical presentation of the movement between the checkpoints of one or all of the observed competitors (Figure 1).

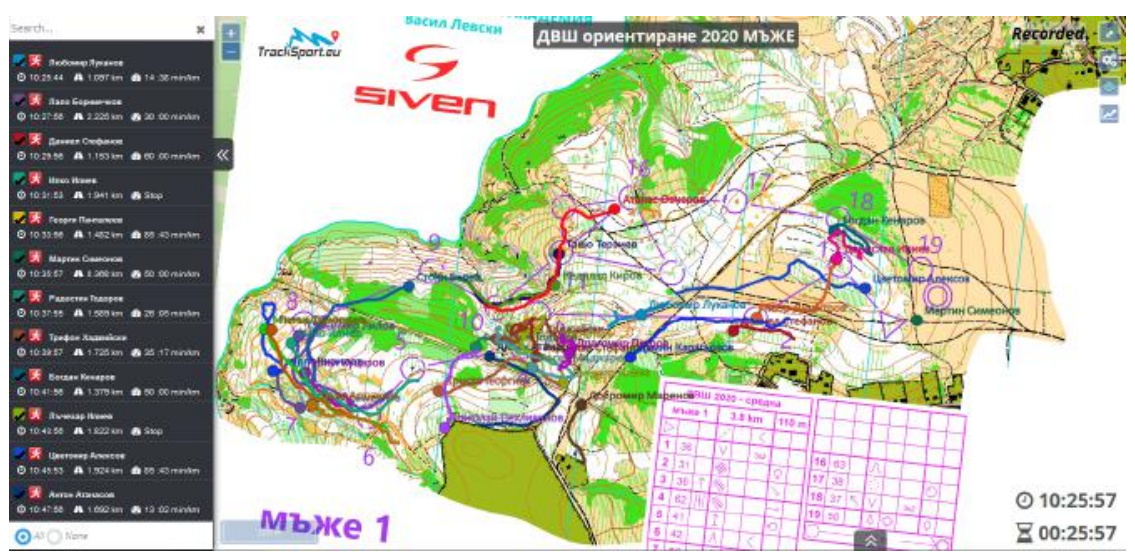

Figure 1. Visualization of the movement of male competitors 
Each participant has a GPX file which is saved in the system, through which it is possible to measure his speed, distance and elevation during the race. Figure 2 shows a graph of the elevation of the winner in the men's race - major Atanas Ovcharov. Its maximum elevation is $830.4 \mathrm{~m}$, minimum $734.5 \mathrm{~m}$ and average $790 \mathrm{~m}$. This option allows quantitative comparison of the elevation gathered in the race (Figure 3).

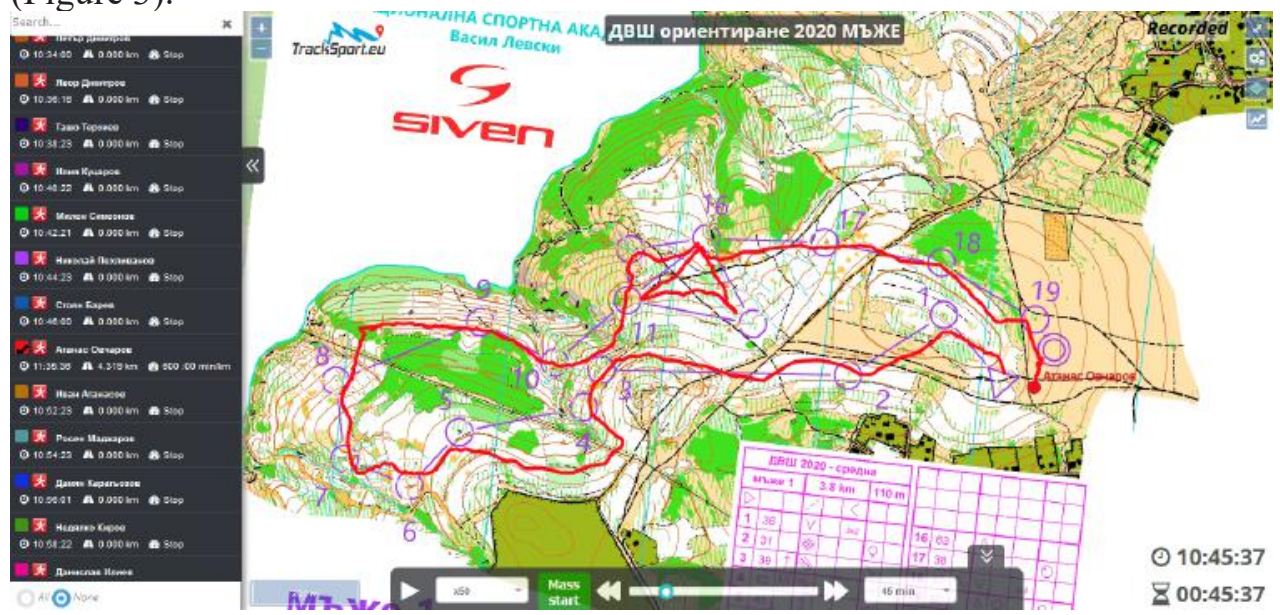

Figure 2. Visualization of the movement of major Atanas Ovcharov winner of the race

The graphs show and the real distance run by the competitor. The $3.8 \mathrm{~km}$ long route on the map turns in $5.9 \mathrm{~km}$ real distance on the terrain. (Figure 2 and Figure 3). There is also possibility to measure the maximum and average speed of the competitor.

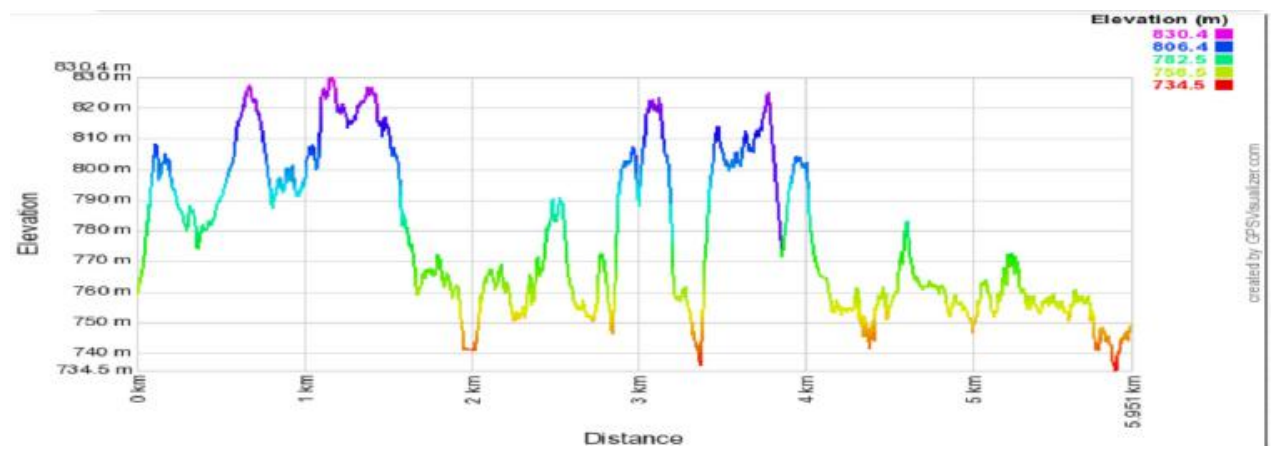

Figure 3. Elevation of the race of the winner in the Bulgarian military championships 2020 - major Atanas Ovcharov 


\section{Discussion}

Despite the excellent visualization and analysis possibilities of the Tracksport system, it still needs some future improvements. Real -time statistics and comparison of the parameters of the races for different competitors might be included. The increased interest in the live GPS tracking can be synchronized with video recording, which will increase the attractiveness. Synchronization with video recording is possible, but this is also within the competence of the video recording platforms.

\section{Conclusion}

The use of live GPS tracking is already an essential part of Bulgarian military championships. An information base of the conducted tracking is preserved and is available at any time for review, analysis and comparison.

The application of the Tracksport system allows an accurate and objective quantitative analysis of the movement of the competitors.

Live tracking contributes to greater safety and security of the competitors. A lost or severely injured competitor could be easily positioned on the map during the exact location of the Tracksport system.

The presence of GPS tracking during military orienteering events is of great importance because it increases the spectator's interest and provides direct information about the competition, which in turn makes the sport more attractive for advertising and sponsorship.

\section{NOTES}

1. IOF, 2021. Competition rules for International Orienteering Federation Foot Orienteering Events, IOF, p.3 [ viewed 20April 2021]. Available from https://onedrive.live.com/embed?resid $=663580750 \mathrm{D} 0 \mathrm{C0BCE} \% 2146285 \& \mathrm{a}$ uthkey=!AJuccVZHkUEJh7Q\&em=2\&wdHideHeaders=True\&wdDownloa dButton $=$ False

2. Tzenkov, V., 2014. Tracksport [viewed 25may 2021]. Available from https://gps. tracksport.eu/events

\section{REFERENCES}

Kocbach, J., 2011. GPS-analysis: Revolution for analysis of technique in the sport of orienteering [viewed 10March 2021]. Available from: https://www.olympiatoppen.no/om_olympiatoppen/stoetteordninger/ stipend_til_lag/media17560.media

McNeil, C., 2010. Teaching Orienteering, Crowood: Sports Guides Orienteering. 
Sirakov, I. \& Belomazeva-Dimitrova, S., 2016. Savremenni sredstva za prosledyavane na dvizhenieto na sastezateli po orientirane. Sbornik trudove ot mezhdunarodna nauchna konferentsia „Pedagogichesko obrazovanie - traditsii i savremennost", 324-329 [ In Bulgarian].

Sirakov, I. \& Belomazheva-Dimitrova S., 2019. Analiz na vazmozhnostite za prilozhenie na GPS tehnologiite i softuernite produkti v sporta orientirane. Sbornik ot Edinadeseta mezhdunarodna nauchna konferentsia ",Savremenni tendentsii na fizicheskoto vazpitanie i sporta”. Sofia: Sv. Kliment Ohridski, 288 - 298 [In Bulgarian].

Shandurkova, S., 2019. Prilozhenie na sistemata za GPS prosledyavane Loggator v svetovnite serii po planinsko byagane skyrunning v Bulgaria. Sport i nauka - Sport and science (3), 61-67 [In Bulgarian].

Shandurkova, S., Galov M. \& Iliev L., 2008. Optimizirane na trenirovachnia protses po orientirane s GPS navigatsia. Sport i Nauka-Sport and science (Izv. br 2) $82-85$ [In Bulgarian].

Shopov, A., 2019. Topografska podgotovka i orientirane - Topography and orienteering, Sofia: NSA Press [In Bulgarian].

$\triangle$ Silvia Shandurkova

http://orcid.org/0000-0002-7084-3340

National Sports Academy "Vassil Levski"

Sofia, Bulgaria

E-mail: silvia.shandurkova@gmail.com 